\title{
«Ingen udediske mennesker skal stå til troende» Lagmannsdømming i nordnorske trolldomssaker 1647-1680.
}

\author{
Av Rune Blix Hagen
}

Preprint, akseptert versjon av artikkelen «Ingen udediske mennesker skal stå til troende». Lagmannsdømming i nordnorske trolldomssaker 1647-1680. Publisert i Heimen Lokal og regional historie 2015; Volum 52.(2) s. 148168.

Publisert versjon i fulltekst fra https://www.idunn.no/heimen/2015/02/

«Vi er kommet fram til 25. juni 1663, da det berammede lagting på Vardshus skal finne sted. Lagmannen Schønnebøl, en stor og mektig herre, med høy panne og skarpskårne trekk, og med øyne som kan være både inkvisitorisk spørrende og mildt bebreidende, sitter ved dommerbordet. Ved siden av, amtmannen, som ser noe nedtrykt ut, sorenskriveren, som tilsynelatende bare er opptatt med sine papirer, og fogden, hvis ansikt ikke røper noe som helst. Presten og fruen sitter for seg selv, høytidelige og oppmerksomme, og ved prestefruens side, fru Wiwicke, blek og tynn, med blikket rettet bekymringsfullt mot sin mann. Foran dommerbordet står Malene (Magdalena) Jacobsdatter, merket av fengselsoppholdet, hun stirrer stivt fremfor seg, og holder sitt store sjal sammen i halsen»

-Kirsten Bergh (NRK, manus til skuespill fra 1968)

Ettersom Mari Olsdatter er kun for et barn å regne

og har løyet både på seg selv og andre,

vet jeg herom i denne sak ikke annerledes å kunne kjenne og dømme

enn at nevnte lille tøs blir å sende herfra stedet

og til Bergen for der å forbli i tukthuset en tid.

Manderup Peders. Schiønebøll ${ }^{1}$

Til tross for både bortvisning fra Finnmark og opphold på tukthus er egentlig dette en svært så oppsiktsvekkende og mild domsslutning fra lagmannens bes $\varnothing \mathrm{k}$ og embetsgjerning i slutten av juni 1663 i fiskeværet Vardø. Etter at den lokale fogden, Niels Sørensen Fiil, noen måneder tidligere hadde bedt tingsretten om å avsi båldom over 12 år gamle Mari Olsdatter, fikk sorenskriveren Lauridtz Bøgvad sammen med noen modige lokale rettsmenn anket saken. Ankesaken kom opp i forbindelse med lagmannens sesjoner og kontroll av rettsforholdene $\mathrm{i}$ Finnmark sommeren 1663. Ikke bare dømte han helt annerledes enn hva påtalemyndighetene $\emptyset n s k e t$ i saken mot den unge jenta, men samtidig ble en rekke andre pikebarn og voksne kystkvinner som satt i forvaring i det såkalte trollkvinnefengselshullet på Vardøhus festning, blankt frifunnet for alle trolldomsanklager. Det dreide seg om et titall mennesker som nå kunne forlate «hullet» som frie individer renvasket for alle alvorlige mistanker og beskyldninger. Den uredde og selvstendige embetsmannen som med loven i hånd grep inn mot forfølgelse av kystkvinner i nord var lagmannen i Hålogaland, Mandrup Pedersen Schønnebøl. Og det var ikke første gang han var i Finnmark og satte anklagede trollfolk fri. Hans rettsmisjon om å holde fast ved lov og rett kombinert med en mulig trolldomsskepsis $\mathrm{i}$ sin mentale bagasje begynte såpass tidlig som i 1647. 
Fra 1647 og utover blir Schønnebøl en slags heksenes advokat i nord. Gjennom å stille svært strenge krav til vitnehabilitet representerer han en viss grad av rettssikkerhet overfor mistenkte nordnorske trollfolk. Han utnytter de smutthullene datidens lovverk faktisk ga for rettsvern og bruker dem til å frikjenne mennesker for trolldomsanklager. «Ingen udediske mennesker skal stå til troende» får stå som hans juridiske motto. Schønnebøl fulgte konsekvent prinsippet om at ingen tidligere dømte personer hadde anledning til å vitne mot andre. ${ }^{2}$ For han var dette en ufravikelig rettsprosedyre som også skulle komme til anvendelse i saker om trolldomskriminalitet. Med henvisning til gjeldende dansk og norsk lovgivning brukte han dette argumentet i trolldomsprosesser både i Nordland og Finnmark.

Av Tingfarebolken i Norsk lov av 1604 gikk det fram at det skulle avvikles lagting ved fiskeværene i Finnmark hvert tredje år. På 1600-tallet gikk det relativt ofte mer enn tre år mellom hvert lagting i Finnmark. Periodene mellom hver gang lagmannen bes $\emptyset$ kte Finnmark, fikk stor betydning for intensiteten av hekseprosesser i området. I mellomperiodene kjørte underretten trolldomssaker så å si etter eget skjønn. Lagmannen satt inne med juridisk kompetanse og myndighetsautoritet. På en helt annen måte enn fogden, sorenskriveren og den lokale domsnemnd var han lovkyndig og utøvde rettspraksis etter lovens bokstav. Han kunne derfor føre en viss faglig kontroll med underrettens dommere. Dessuten tok han sine avgjørelser på et friere grunnlag når det gjaldt konflikter i lokalsamfunnene. Lagmannen hadde ikke på samme måte som underretten og den lokale påtalemyndighet sin sterke forankring i nærmiljøet.

Dersom Mandrup Schønnebøl hadde reist på inspeksjonsrunde til Finnmark oftere enn han var pålagt, kunne mange menneskeliv vært spart. På den annen side: Dersom han ikke hadde grepet inn slik han faktisk gjorde mot forfølgelsen av trollfolk i Finnmark, ville en av de verste menneskeforfølgelsene i norsk historie sett enda verre ut. Langt over 100 mennesker ville da ha stått på lista over brente trollfolk i Finnmark, herunder flere mindreårige «trollunger». Dette er altså mannen som fra midten av 1600-tallet reiste stor tvil om bevisførsel og tortur for å framtvinge tilståelser. At Schønnebøls rettsinnsikt og strengt legalistiske anvendelse av sikkerhetsventiler innebygd i datidens rettsvesen gradvis ble tatt til følge, førte på sikt til avskaffelsen av mange svært tvilsomme rettsmidler i norsk rettspraksis. Schønnebøl burde ha hatt en høyst fortjent plass som sentral aktør i norsk rettshistorie. ${ }^{3}$ Lagmannens rettspraksis er også et uttrykk for at det midt under noen av de verste forfølgelsesbølgene eksisterte ulike syn på trolldommens realitet og at momenter av tvil og skepsis var til stede. Det var aldri entydig konsensus verken blant lek eller lærd når det gjaldt oppfatningen av troen på virkningsfull magi og eksistensen av farlige trollfolk. Og nettopp 
blant tvilerne finner vi spiren til at den europeiske hekseforfølgelsen gradvis avtok, for så å opphøre helt utover 1700-tallet. ${ }^{4}$

Når vi leser de fyldige og gamle rødbrune papirene fra trolldomssakene i Finnmark, sitter vi vanligvis igjen med et svært så nedslående inntrykk. De aller fleste rettergangssakene ender med domsslutningen «straffes på hennes liv til ild og bål». Derfor er det faktisk befriende å finne dokumenter som viser at enkeltmennesker kunne ta til motmæle mot heksehysteriet særlig i Øst-Finnmark - enkeltmennesker som hadde kraft til å stå fram og forsvare mistenkte trollkvinner. Hvem var denne uredde lagmannen? Hvordan dømte han og hvordan rettferdiggjorde han sin rettspraksis i saker som hadde med alvorlig kriminalitet å gjøre?

\section{Liv og virke}

Mandrup Pedersen Schфnnebøl ble født 18. mai 1603 på Steigen lagmannsgård i Nordland. Han var sønn av Gudrun Christopherdatter Grøn (1570-1603) og Peder Hanssen Schønnebøl (ca.1530-1610). Schønnebøl-familien tilhørte en dansk adelsslekt med røtter på Fyn. Faren hadde vært fogd over Salten len fra 1575 til 1578 og lagmann i nord fra 1587 til sin død i 1610. Siden mora også døde mens Mandrup var mindreårig, vokste han opp på Bodøgaard hos lensherre over Nordlandene, datidens Nordland og Troms, Hartvig Bille som var slekt av familien Schønnebøl. Svoger til Mandrup, som etter hvert også ble hans svigerfar, var forgjengeren i embetet, lagmann Jørgen Henriksen Staur. Staurs embetsperiode strakte seg fra 1616 til 1648. Flere personer i nær slekt med Mandrup fulgte i hans embetsstilling mot slutten av 1600-tallet og et stykke utover 1700-tallet. Slik sett kan vi tale om et slags lagmannsaristokrati gjennom fem sammenhengende generasjoner. Hans Eyvind Næss har beskrevet lagmannsembete i Steigen i denne perioden som et 160-årig familieforetak. ${ }^{5}$

Mandrup fikk skolegang først i Bergen fra 1616 og deretter i Århus fram til 1620, før han gjorde militær karriere i det nyetablerte norske militærvesenet. Han skal i tillegg ha vært fire år i hollandsk militærtjeneste, fra 1622 til 1626. Deretter tjenestegjorde han både som major og kaptein i hæren i Danmark-Norge fram til høsten 1629. Fra denne tid av er han på plass i Nordland. I 1632 giftet han seg med Maren Jørgensdatter Staur (1606-1685) og bosatte seg delvis på Bertnes, en fri setegård utenfor Bodø, og delvis i Steigen, på den adelige setegården Skånland (fra 1661). ${ }^{6}$ På svigerfarens oppfordring gjennom søknad til de sentrale myndigheter i København fikk han ekspektanse (ventebrev) på lagstolen såpass tidlig som i 1636. Under krigen mot Sverige, den såkalte Hannibalfeiden 1643-45, bar Mandrup ansvaret for utskrivning av soldater fra Nordland. Militære oppgaver fikk han dessuten i forbindelse 
med Karl Gustav-krigene, i perioden 1657-1660. Som representant fra nord og i kraft av sitt embete var Mandrup til stede ved kongehyllingen av Frederik III (1648-1670) i Christiania i august 1648. Ved denne anledningen, mens han allerede hadde påbegynt sitt virke som lagmann, fikk han bekreftet sin stillingsrett til Steigen lagstol. Mandrup ble viselagmann i Hålogaland lagdømme da hans svoger og svigerfar døde og var virksom som viselagmann fra sommeren 1647. På 1600-tallet omfattet lagdømmet det vi i dag betegner som Nord-Norge. ${ }^{7}$ Forgjengeren Jørgen Henriksen Staur ser ut til å ha gått bort mot slutten av 1646, slik at Mandrup fungerte i stillingen allerede før han fikk formell bestalling som lagmann i brev av 22. august 1648. Han satt i embetet til han selv døde i Steigen 22. juni 1682. I 1660-åra var Mandrup ledende i arbeidet med å få utarbeidet en matrikkel, ei jordbok, for Nordlandene. I sin aktive periode deltok han i flere sammenhenger utenfor sitt eget embetsdistrikt, slik som ved herredagen i Bergen i 1652. Ekteparet fikk 15 barn sammen, blant annet sønnen Fredrik Henrik (f. 1656) som ble lagmann i 1689 og som satt i lagstolen fram til 1710. Hans svigersønn, Christen Jensen Munkgård, ble viselagmann og overtok lagstolen etter Mandrups død. ${ }^{8}$

Det er vanskelig å finne ut av Mandrup Schønnebøls juridiske skolering. Det er mulig at han var selvlært og leste seg opp på lovgivning, og annen juridisk litteratur, etter at han fikk ekspektanse på stillingen i 1636. Og høyst sannsynlig har han kjent til Den rette Jüdske Lowbog fra 1590 og 1642 - ei grunnleggende lovsamling som blant annet inneholder de bestemmelsene han dømmer etter i trolldomssakene. Det er vel god grunn til å tro at han arvet et bibliotek med hovedvekt på juridisk litteratur etter sin far og svigerfar, og forgjenger, $\mathrm{i}$ lagstolen.

I Mandrup Schønnebøls embetsperiode 1647-1682 ble minst 71 mennesker formelt anklaget for trolldomsvirksomhet i Finnmark. Lagmannen var til stede under behandlingen av 23 slike saker. Han frifant 18 trolldomsmistenkte kvinner og ungjenter, en mann og ei kvinne fikk bot, ei ungjente, den 12 år gammel Mari Olsdatter, ble, som vi så ovenfor, dømt til opphold på barne- og tukthuset Bergen, en dom som for øvrig ikke ser ut til å ha blitt satt ut i livet. Utover disse trolldomssakene avsa Schønnebøl dessuten dødsdommer over to trollkvinner i 1656.

\section{«Ingen udediske mennesker må stå til troende i hva de sier»}

Mandrup Schønnebøls aller første embetshandlinger som lagmann i Nordlandene og Finnmark besto faktisk i å oppheve dommen over ei kvinne som var dømt som trollkvinne av underretten. Under lagtingssamling i Vardø 4. juni 1647 frikjente lagmannen Maren 
Jacobsdatter, som hadde vært holdt i fengsel på Vardøhus slott i bolt og jern i 16 uker. Trolig var hun første fange i det nybygde «trollkvinnefengselshullet» som lensinnehaver John Cunningham fikk ført opp inne på festningsområdet på tampen av 1640-åra. Cunningham var for $\varnothing v$ vig til stede under lagtingets sesjon i Vardø i 1647 der Schønnebøl, som den første rettsaktør i Norge, tok et systematisk oppgjør med hjemmetingets rettspraksis i trolldomssaker. Dommen over Maren Jacobsdatter fra førsteinstansen ble «casserit» og kjent «machtisløs». Sorenskriverens og de lokale lagrettemennenes dom ble opphevet. Lagmannen slo fast at dommen ikke var rettmessig og understreker at domsslutningen fra hjemmetinget ikke skulle være Maren Jacobsdatter til hinder og skade på navn eller rykte i noen måter. I Lagmannens dom heter det at ingen udediske mennesker må stå til troende i sine beskyldninger. Som lovgrunnlag henviste Lagmannen til Koldingske recess fra 1558, artikkel 18. ${ }^{9}$ Dessuten var Maren bare utlagt av en person, noe som ikke var rettslig holdbart. Vedkommende hadde ikke vitnehabilitet fordi vitnet tidligere var dømt som kriminell, altså en udedisk person, ifølge Schønnebøl. Det er altså to viktige prinsipper som legges til grunn for lagmannens avvisning av saken; at beskyldningene kom fra en forbryter og at det forelå bare én anklage, det vil si at prinsippet om testis unus, testis nullus legges til grunn. ${ }^{10}$

Saken på lagtinget tok til ved at Maren Jacobsdatters ektemann, bergensborgeren Søren Nielsen, stevnet sorenskriveren og hans meddommere for uriktig dom. Det ble ført flere vitner i saken på 1647-lagtinget. Sorenskriver Niels Jensen Zahls dom ble kjent maktesløs, og han måtte dekke saksomkostninger, stort sett utgifter til forvaring med kost og losji, på 40 daler. Hennes mann hadde båret mat til henne mens hun satt $\mathrm{i}$ «hullet», kom det fram under sesjonen. Sorenskriveren fikk dessuten bot for sin urettmessige dom, mens lagrettemennene blir forskånet for bot fordi de ikke visste bedre. «Laugretteismenderne for nogen bøder att vere forskonnit, efterdi de haffde iche bedre vidende», som det heter hos den unge og nye lagmannen i nord. ${ }^{11}$ Lekmennene i underretten var unnskyldt på grunn av sin uvitenhet, mens sorenskriveren nettopp burde ha utvist bedre skjønn og kjennskap til gjeldende lov og rettsprosedyrer. Schønnebøl presiserte imidlertid at sorenskriveren fikk beholde stillingen. Men sorenskriver Niels Jensen Zahl dør kort tid etter lagtinget i 1647, og ved lagtinget i 1650 dømmes hans etterlatte hustru, Helvig Rasmusdatter, til å betale 40 slette daler til Søren Nielsen, ektemannen til den frikjente kvinna.

Det var en mann med navn Samuel Skarff som på bakgrunn av det ene vitneprovet opprinnelig hadde gitt Maren full sak. På lagtinget i mai 1650 fulgte Schønnebøl opp saken og dømte Skarff til bolt og jern og dermed til å inntre i samme fengsel som Maren hadde sittet, i 16 uker. Dette var i realiteten et sterkt signal og en advarsel til allmuen om risikoen forbundet 
med å anklage sine nærmeste naboer for hekseri uten saklig grunnlag. Saken har for øvrig videre forgreininger til en drapssak på lagtinget i mai 1653 hvor Schønnebøl dømte Hans Pedersøn fredløs og til å «rømme landet» fordi han hadde tatt livet av Samuel Skarff.

\section{Fra lagtingets sesjoner i Finnmark i 1650 og 1653}

Under lagtingets sesjon i Loppa 5. juli 1650 fikk fisker Peder Svendsen dom for å ha kjøpt helbredelse for sykdom. Her handlet det om hvit magi, eller som det heter i rettens begrunnelse, for «å ha søkt ulovlige midler til å la seg kurere» hos en same med navn Oelle Kierelsen fra Tromsøysund. Peder Svendsen dømmes altså lovmessig som medviter etter 1617-forordningen. Lagmannen satte straffeutmåling til åpenbarlig skrift og bot i form av åtte $\emptyset$ rttuger og 13 pund sølv, alt i tråd med forordningens bestemmelser om trollfolkenes kunder.

Den neste lagtingsesjonen i Finnmark fulgte tre år seinere, i 1653. ${ }^{12}$ Flere av trolldomssakene fra kystværet Omgang sto på dagsordenen, og Mandrup Pedersen Schønnebøl frikjente i alt fem kvinner. De var alle anklaget av ei trollkvinne som tidligere hadde fått sin sak pådømt. I argumentasjonen fra lagmannen angående de fem kvinnene var beskyldningene båret fram av en «udedisk» person og kunne derfor ikke «stå til troende». Kirsten Michelsdatter fra Omgang, Anne Bjørnsdatter fra Berlevåg, samekvinna Berrette fra Gamvik, Berigette Simensdatter, også fra Gamvik samt Sigri Tørresdatter fra Steinvågen gikk alle fri. I realiteten var det tale om at Lagmannen rett og slett stoppet en større hekseprosess før den hadde kommet skikkelig i gang. I rettsbelæringen overfor tingretten presiserte han at livs- og æressaker skulle dømmes i Lagmannens nærværelse. Dette er også et tidlig og sterkt signal om lagmannsrådføring i alvorlige saker. Automatisk appell i kriminalsaker hvor dødsdom var aktuell som straffereaksjon ble først innført i Danmark-Norge atskillig seinere.

Ved sesjon i Skjøtningberg 20. juni 1653 avviste Schønnebøl trolldomsanklager mot to kvinner, Ingeborg Jonsdatter og Aagaatte Jacobsdatter, begge med bopel i fiskeværet Kjøllefjord. Som lovgrunnlag henviste Schønnebøl igjen til Christian 3.s recess om at udediske mennesker ikke står til troende, og at utleggelsen og eventuell tidligere dom ikke skal være dem til hinder og rykte i framtiden. Schønnebøl tok dessuten aktivt i bruk skussmålsordningen. Mistenkte trollfolk hadde ut fra loven mulighet for å renvaske seg med ed fra naboene. Gjennom vitneprov og edsavleggelse kunne naboene gå god for den tiltalte, det vil si ved å gi henne et godt skussmål og omdømme. I saken mot Kirsten Michelsdatter fra Omgang heter det at lagmannen spurte tingallmuen om de visste noe om henne, om hun hadde lovet noen ondt og om noen virkelig hadde merket hennes forbannelser. Ingen sto fram med beskyldninger. Derimot svarte den tilstedeværende allmue at de ikke kjente til noe vondt om 
Kirsten, og ga henne et godt skussmål ved å understreke at hun var et ærlig og kristelig menneske. Akkurat det samme gjentok seg i saken mot Ingeborg Jonsdatter fra Kjøllefjord. Hun var en ærlig og kristelig dannekvinne, svarte allmuen, da de ble bedt om sin uttalelse. I forbindelse med frikjennelsen presiserte Schønnebøl at ingen heretter skal «lade høre eller breyde» henne eller hennes barn dersom de vil unngå straff etter loven.

Fra rettsprotokollene i Finnmark ser vi tydelig at hjemmetinget dømmer mer forsiktig i trolldomssaker umiddelbart i kjølvannet av lagmannens syv frifinnelsesdommer i 1653 . Vi kan gå ut fra at sorenskriver i lenet, Anders Christensen, som fulgte med lagmannen på reisen til kystværene i 1653, har blitt grundig rettsbelært når det gjaldt behandlingen av slike saker. Gang på gang slo Schønnebøl fast at «ingen udediske mennesker må stå til troende i hva de sier», det vil si at beskyldninger fra andre trollfolk ikke hadde rettslig tyngde og skulle avvises. Lagmannen hadde nok i tillegg hatt sitt å si om underrettens tiltro til tvilsomme og ikke-hjemlede rettsmidler slik som å kaste folk på havet for å avgjøre om de var skyldige eller ei. Både i 1654 og 1655 opptrådte førsteinstansen kritisk og selvstendig eksempelvis med hensyn til aktoratets krav om vannprøve.

I en sak fra april 1654 mot to mistenkte trollkvinner fra Kiberg, Marette Rasmusdatter og Sigri Olsdatter, ønsket fogd Jørgen Nielsen å prøve dem begge på sjøen. Tilsynelatende uventet og overraskende fikk han ikke medhold i kravet. Lokalretten med sorenskriveren i spissen avviste kravet om å overlate kvinnene til bøddelens hender og uttalte at loven ikke sier noe om vanntesten. Dessuten er de to kvinnene uberyktet, det foreligger ingen anklager fra ærlige personer, bemerker retten. Utleggelsene fra den dødsdømte trollkvinna Karen Jonsdatter holdt ikke som bevis nettopp fordi beskyldningene kom fra en kriminell person som retten ikke kunne feste tillit til. Avgjørelsen førte til sterk konflikt mellom fogden på den ene siden og sorenskriveren på den andre. Sorenskriver Anders Christensen måtte fratre sin stilling for en stund og ble erstattet av Abraham Lockert. Helt i tråd med lagmannens rettsbelæring fant ikke den lokale retten lovgrunnlag for anvendelse av vannprøven. Det er spor og etterdønninger av lagmannens strengt lovmessige vurdering vi finner i Anders Christensens avvisning av vannprøven under tingmøtet i Kiberg. ${ }^{13}$

Underrettens avvisning av fogdens krav fra april 1654 er både oppsiktsvekkende og interessant. Det er første gang under trolldomsprosessene i Finnmark at vi kan spore en smule kritikk av prosessforløpet fra lokalrettens side. I realiteten er vi her vitne til et motsetningsforhold mellom fogden Jørgen Nielsen og sorenskriver Anders Christensen. Og bråk ble det. Umiddelbart etter tingsamlingen i Kiberg 1. april 1654 fikk Anders Christensen avskjed som sorenskriver, trolig av lensherren selv, Jørgen Friis. I all hast utnevnte han 
Abraham Lockert til ny skriver. Lockert opptrer i sin nye posisjon allerede ved den påfølgende tingsamlingen 5. april i Vardø. Denne samlingen åpner med at Anders Christensen stevnes for å ha misbrukt sin stilling som sorenskriver. Oppsigelsen var klart usaklig, vurdert ut fra samtidens målestokk. Christensen godtok da heller ikke stevningen og møtte ikke fram på tinget. Derimot fikk tinget overbrakt et brev hvor han skriver at «ingen her på stedet er min

overdommer». ${ }^{14}$ Christensen ble etter kort tid gjeninnsatt i stillingen, sannsynligvis etter krav fra lagmannen. Pussig nok rammes Anders Christensens hushold av djevelskap i slutten av 1654, noe som førte til at han selv opptrådte som hovedanklager i en trolldomssak som endte med båldom. Christensen døde i 1659 og deltok altså ikke som rettsaktør i den store heksejakten noen år seinere.

\section{De to dødsdommene i 1656}

Tre år seinere var det klart for et nytt besøk av lagmannen ved tingstedene i Finnmark. Igjen sto det nye trolldomssaker øverst på sakslista for Schønnebøl under hans virke i Vardø 20. mai 1656. Følgende tre kvinner skulle få sin skjebne beseglet av lagmannen:

- SIRI CHRISTOPHERSDATTER, ugift tjenestejente bosatt i Vard $\varnothing$, opprinnelig fra Bjarkøy i Troms.

- MARI THOMMISDATTER, ugift tjenestejente bosatt i Vardø, opprinnelig fra Bergen. - METTE NIELSDATTER, gift bergenskone bosatt i Vardø.

Den endelige domsslutningen var tilsynelatende overraskende sett i lys av Schønnebøls rettspraksis i slike saker både i 1647 og, ikke minst, i 1653. Ganske uventet, får vi vel si, felte han dødsdom over Siri og Mari. ${ }^{15}$ I lagmannsdommen het det at «Siri Christoffersdatter og Mari Thommisdatter, kjent som Lille Mari, skal begge lide på sin hals for å ha forbundet seg med djevelen. Mette Nielsdatter, derimot, skal frikjennes for alle anklager». Dommen over de to tjenestejentene begrunnes med henvisning til deres egne tilståelser. Schønnebøl argumenterte med at den første tilståelsen fra underretten måtte stå ved lag og viste til lovens bestemmelse om at man skal dømmes etter egen tilståelse. Når det gjaldt Mette, hadde hun ikke tilstått og var utelukkende utlagt som medskyldig av Siri Christophersdatter. Dermed «siden Siris beskyldning står alene, kan hennes ord ikke stå til troende», framholdt lagmannen og lot Mette gå fri. Fogden, Abraham Lockert, på sin side ville ha sak fordi Mette var anklaget for å være skyldig i trolldomskunster av Siri. Lagmannen avviste altså fogdens begjæring fordi det bare fantes ett vitne, og ett vitne bar ingen beviskraft. Dessuten var det ikke snakk om noe ærlig vitne - beskyldningene kom jo fra en uærlig person, det vil si fra en forbryter og synder, og var derfor ikke troverdig. I motsetning til Lille Mari og Siri, berget Mette livet. Mette Nielsdatter fikk dessuten et godt skussmål og plettfri vandelsattest fra hele 
tingallmuen. De hadde ingenting å utsette på hennes væremåte. Mette var gift med Henrich Pedersen, lagrettemann, bergensborger og framtredende person i fiskeværet. Ekteparet bodde i Krogen, som var et litt bedre strøk i øysamfunnet. Med et nettverk i ryggen sto Mette bedre beskyttet mot stygge rykter i lokalmiljøet enn de to andre. Lille Mari var ugift, ung, enfoldig og ubeskyttet. Hun sto i en mer utsatt og sårbar posisjon, var lettere å mistenke og enklere å fjerne.

Ugifte, enker og enslige var gjennomgående mer sårbare for hekseanklager enn andre kvinner. Dette mønstret står fram som et klart karaktertrekk ved hekseprosessene stort sett overalt i Europa. ${ }^{16}$

En mindre detalj i Schønnebøls opptreden i Vardø i mai 1656 er at de to tjenestejentene ble dømt «til å lide på sin hals» og ikke til å brennes på bål. I datidens domspraksis betydde faktisk dødsstraff i form av halshugging i stedet for bålbrenning straffenedsettelse. Samtidig er det et klart trekk ved domspraksisen til Schønnebøl at han dømmer legalistisk, det vil si strengt etter lovens bokstav. Den dansk-norske trolldomsloven fra 1617 krevde dødsstraff «uten all nåde» for djevlepakt, men sa faktisk ingenting om brenning. Og det går ikke uttrykkelig fram av loven hvordan slike folk skulle eksekveres. Derimot heter det at «de, som sig med saadanne folk indvikler och ved deris troldom noget sig understaar at lade forrette, skal straffis paa deris hals uden ald naade». ${ }^{17}$ Brenning av trollfolk i tidlig nytid hentet sin hjemmel fra sedvane og i enkelte utsagn fra Martin Luther. Det var først ved innføringen av Christian Vs Norske lov i 1687 at bestemmelsen om at trollfolk skulle lide på bålet, kom inn i det formelle lovverket. Her sto det svart på hvitt at trollfolk skulle kastes levende på bålet og oppbrennes.

\section{9 - Lofoten i Nordland}

Etter 1656 går vi inn i en roligere fase når det gjelder trolldomsanklager i Finnmark. Ut fra de gamle rettsdokumentene kan vi se at det ulmet med trolldomssnakk like under overflaten, men det kom ikke til formelle anklager. I tråd med instruksen om å sette lagting i Finnmark hvert tredje år, reiste Schønnebøl nordover i 1659 og avviklet sesjoner ved åtte fiskevær i løpet av juni og juli. Sakene var primært av økonomisk karakter og handlet om skatt og bergenskjøpmennenes plikter og rettigheter. Ingen trolldomssaker sto på sakslista verken i Vardø eller andre steder i hans nordøstlige embetsdistrikt,

Likevel fikk Mandrup Schønnebøl med trolldom å gjøre, også i 1659, om ikke i Finnmark så i hans eget nærområde. Denne saken er av interesse ikke minst for å konstatere at 
hans dømming i slike saker er konsekvent og ikke kan knyttes til den nokså spesielle situasjonen lenger nordøst.

Ved et såkalt sogneting i Vågan i Lofoten den 2. desember 1659 frikjente lagmannen Karen Pedersdatter Kleppstad for trolldomsbeskyldninger. Hun var dømt til døden av underretten på bygdetinget for å ha satt ondt på mennesker og dyr samt å ha misbrukt sakramentet. I det siste tilfellet handlet det om at Karen i hemmelighet hadde tatt med brød og salt ut fra kirken. Schønnebøl opphever hjemmetingsdommen avsagt i Valberg i oktober 1659 på en måte som vi etterhvert har blitt kjent med: Allerede dømte vitner kan ei stå til troende, og hun skal være «fri for disse bemelte letferdige Quindfolchis w-sandferdige tillagelse». For misbruk av sakramentet, tiltenkt som hvit magi til helbredelse, satte Lagmannen straffen til kirkelig disiplin, og et krav om at hun skulle gi tre Riksdaler til de fattige for hennes misbruk av saltet. Karen hadde tatt med saltet ut av kirken, og hun tilsto at hensikten var helbredelse gjennom magisk-rituell anvendelse av det helliggjorte sakramentet. Lagmannen underkjenner altså den alvorlige djevlepaktdommen, men dømmer Karen etter den noe mildere paragrafen om helbredende magi i hovedforordningen om trolldomsvirksomhet fra 1617. Som i Finnmark ga han underretten i Lofoten en kraftig reprimande ved å vise til «Tingfar Balchen 4 kap.» samt «mandhelg Balchen 15 cap.» der det framgår at retten skal rådføre og dømme sammen med Lagmannen. Schønnebøl refererer dessuten til Christian den fjerdes store recess av 1643, pag. 202, for gjenopptakelse av saken - alle ære- og livssaker skal forelegges lagmannen, det vil si underkastes lagmannsrådføring. ${ }^{18}$ Igjen er det påkrevende for lagmannen å utnytte loven og retningslinjene for rettsprosedyrer. Og han er i 1659 som i Finnmark tidligere, noe forut for sin tid angående anvendelse av appell i alvorlige saker. Loven om tvungen automatisk appell og anke for dødsdømte kom i 1687/88, for så å bli endelig stadfestet først i 1719. ${ }^{19}$ Ikke bare i Finnmark, men også ellers i Norge, må fraværet av et effektivt og fungerende rettslig appellsystem trekkes fram som noe av bakgrunnen for at førsteinstansens trolldomsprosesser fikk fortsette fram til 1687. Schønnebøl var tidlig ute og viser hvordan det var lovmessig mulig for han å begrense omfanget av forfølgelse før denne tid.

\section{Den store oppvasken sommeren 1663}

I forbindelse med Norges verste forfølgelse av trollfolk, som foregår under dramatiske omstendigheter i Øst-Finnmark seinhøsten 1662 og vinteren 1663, var det Schønnebøl som definitivt klarte å sette en sluttstrek for det som må kunne betegnes som sosial panikk og heksehysteri. I løpet av noen få måneder pågikk det bokstavelig talt heksejakt på angivelige 
trollkvinner. Rettsforfølgelsen krevde 20 menneskeliv. Ytterligere 10 angivelige trollkvinner og trollunger under 12 år, satt innesperret $\mathrm{i}$ «trollkvinnefengselshullet» på Vardøhus festning da Schønnebøl kom nordover rundt sankthanstider i 1663. Sakene mot barna var anket til lagmannen, mens eksekvering av dødsdommen over de voksne kvinnene rett og slett var utsatt fordi de alle var gravide. Ei av ungjentene ble dømt til et forbedringsopphold ved det nyetablerte barne- og tukthuset i Bergen, mens resten slapp fri, renvasket for alle anklager mot seg. På denne lagtingssamlingen opptrer Schønnebøl langt mer selvstendig og aktivt enn ved tidligere samlinger. Hans funksjon er ikke bare begrenset til dommergjerningen. Ved å kalle inn hver enkelt av de tiltalte, tar han hver og en for seg og spør dem ut om trolldomsanklager og trolldomstilståelser. I ett tilfelle spør han om Mari Olsdatter kan lese noe. Det kan hun og leser høyt for lagmannen og de tilstedeværende. ${ }^{20}$ Schønnebøl tar seg god tid, og hans forhør går over flere dager. Det er i denne fasen av lagtinget at flere bryter ut i gråt og forteller om et skrekkregime med tortur og sterke trusler. De har løyet på seg selv og andre for å unngå fysisk tortur. Dessuten forklarer flere, særlig blant pikebarna, at Anna Rhodius har lagt ordene i munnen på dem. På bakgrunn av disse opplysningene konkluderer lagmannen med at underrettens prosessførsel var foretatt på et sviktende og spinkelt grunnlag. Ut fra egne forhør og undersøkelser avsier Schønnebøl frikjennelsesdommer over samtlige, med et lite unntak, når det gjelder tukthusdommen. Denne gangen, i motsetning til lagmannsdommene i 1656, avviser han ikke bare vitnebevisene, men også tilståelsene fra de tiltalte. Begrunnelsen ligger i de psykiske og fysiske tvangsmidlene som har vært i utstrakt bruk for å få kvinnene til å lyve på seg selv. Vi aner en juridisk utvikling hos lagmannen der han stiller seg kritisk og skeptisk til både vitnehabilitet og egne tilståelser i rettssaker med trolldomsinnhold.

Ved lagtingets sesjon i Vardø tirsdag 23., torsdag 25. og fredag 26. juni 1663 frikjente Mandrup Schønnebøl følgende fire voksne kvinner og seks pikebarn:

- KAREN IVERSDATTER, Vadsø, åtte år. Moren brent som heks i november 1662.

- INGEBORG IVERSDATTER, Vads $\varnothing$, noe eldre søster av Karen.

- MAREN OLLUFSDATTER (Mari Olsdatter), Vadsø, rundt 12 år. Mor og tante ble tidligere brent som trollkvinner.

- KARI NIELSDATTER, Vadsø, hennes mor ble brent som heks i april 1663.

- MAGDALENA JACOBSDATTER, Andersby. Hun fikk dødsdom av førsteinstansen i april 1663, men henrettelsen ble utsatt fordi hun var med barn. Etter frifinnelsen sommeren 1663, ble hun pånytt anklaget for farlige trolldomskunster med krav om dødsdom. Hun frikjennes atter en gang av lagmannen i 1671 (se nedenfor).

- RAGNHILD ENDRISDATTER, Vardø, gravid da hun fikk dødsdom 11. mars 1663 og skulle brennes.

- GJERTRUD SIVERTSDATTER, Vard $\varnothing$, gift med bergensborger. 
- KIRSTEN SØRENSDATTER, Vardø, trolig under 10 år, datter av Gjertrud.

- KAREN NIELSDATTER, Vardø, gift.

- SIRI PEDERSDATTER, Vard $\varnothing$, trolig i tenårene, datter av Karen Nielsdatter. Kan være utsatt for djevleutdrivelse og voldtekt under fengselsoppholdet.

Om de første fire barna heter det i Mandrup Schønnebøls dom at disse fattige, små faderløse barn skal være fri og løslatt. De som har foreldre skal føye seg til dem, og de andre som ikke har foreldre i live må bli tatt vare på av noen her på stedet og oppfostret dem som sine egne barn. Etter at hennes nærmeste slektninger var blitt brent som trollkvinner, ble Mari Olsdatter tatt hånd om av lokalmyndighetene med direkte tilknytning til selve Vardøhus festning. De neste årene går hun som tjenestejente på «slottet». Ingenting tyder på at hun faktisk ble sendt til forbedringsanstalten i Bergen. I 1667 var hun innblandet i en anklage om horeri på slottet. Anklagene gikk ut på at hun skulle ha hatt «legemlig omgjengelse» med klokkeren, Joseph Abrahamsen, i Vardø. I den påfølgende rettssaken kom det fram at amtmannens tjenestejente hadde gått til privat avstraffelse gjennom å piske Lille Mari. Horerianklagene vant ikke fram. Både klokkeren og tenåringsjenta gikk fri for «oppdiktet angiversnakk» og «bygde raab» omkring «utilbørlig beblandelse på slottet». ${ }^{21}$

\section{Trolldomssaker i Finnmark etter 1663}

Den store hekseforfølgelsen i 1662/63 med den etterfølgende juridiske oppvask av lagmannen er på sett og vis utgangen på alvorlige trolldomssaker i Finnmark. Det er kun felt én dødsdom med påfølgende heksebål, i Vadsø, etter denne tid. Imidlertid har Schønnebøl og, andre lagmenn etter han, vært nødt til å avverge nye bølger av trolldomsprosesser i nordområdene.

Magdalena Jacobsdatter, fra Andersby, ikke langt fra Vadsø, ble frikjent for samtlige trolldomsanklager 29. juni 1671 under lagtingets møte i Vard $\varnothing$. Hun ble dessuten tilkjent en erstatning på 12 riksdaler for 33 uker i fengsel, erstatning for «smerte og lidelse», som det heter i Schønnebøls dom. Underfogden, Lauritz Sørensen Faag, ble bøtelagt med 17,5 mark sølv. I tillegg ble anklageren ilagt ei klekkelig bot. Samme Magdalena ble tidligere frikjent av Schønnebøl i Vardø i juni 1663. Ved begge anledningene, både i 1663 og i 1671, tok lagmannen skussmålordningen aktivt i bruk. I begge tilfellene svarte den tilstedeværende allmuen at de ikke visste noe om henne og heller ikke kjente til rykter foruten det som hadde kommet fram under hjemmetingsakten. ${ }^{22}$

I 1680 ble ei kvinne med navn Kirsten Knutsdatter fra Vadsø frikjent på lagting i Vardø 16. juni med henvisning til «recessen pag. 195» og til «MHB 21.cap.» om «mummesag». Alle krav om vannprøve fra underrettet ble blankt avvist av lagmannen, hvor 
det heter om vannprøven - «hvis loven ikke tillater». Denne gangen var det viselagmann og svigersønn av Mandrup Schønnebøl, Christen Jensen Munkegaard, som med all tydelighet dømte i svigerfarens ånd.

Eksempler på lagmenn fra andre deler av landet som så å si fulgte i Schønnebøls juridiske fotspor kan være Peter Carstensen Drejer som var lagmann ved Trondheim lagting fra 1671 til 1703. I trolldomssaker fra Trøndelag i midten av 1670-åra aviste han utleggelser og anklager ved henvisning til recessen om at udediske mennesker ikke har vitnehabilitet. Hans håndtering av trolldomssaker «forhindret en eskalering av trolldomsprosesser i Trondheim og Gauldal». ${ }^{23}$

\section{Regelrytteri, humanisme eller personlig skepsis}

Mandrup Pedersen Schønnebøl er dermed den første fagdommer i Norge som tar til systematisk motmæle mot forfølgelse av trollfolk i nord. I følge rettshistorikeren Hans Eyvind Næss var det ved Schønnebøls inntreden på den historiske scene på midten av 1600-tallet at man overhodet begynte å kritisere rettspraksis i norske trolldomssaker. ${ }^{24} \mathrm{Ja}$, Næss er av den oppfatning at trolldomsprosessenes opphør i Norges skyldes endring i bevisvurderingen gjennom fagdommere. ${ }^{25}$ Samme synspunkt gir historikeren Einar Niemi uttrykk for i sin lokalhistoriske behandling av trolldomsprosessene i Vadsø-området, den delen av Varangerhalvøya som ble hardest rammet av forfølgelsen. Niemi skriver at lagmenn etter hvert slo ned på en god del av torturen og at «reaksjonen mot utartelsene begynte nettopp i Finnmark, i 1650-åra da den nye lagmannen på Steigen, Mandrup Schønnebøl, besøkte tingene her». ${ }^{26}$ «Han banet således vei for avvikling av trolldomssakene», skriver jurist og høyesterettsdommer Aage Thor Falkanger. Falkanger viser i tillegg til Mandrup Schønnebøls håndtering av barnedrapssaker når han skriver om en «uvanlig selvstendig» lagmann som «ikke fravek sin humanistiske linje». ${ }^{27}$ Idéhistorikeren Nils Gilje framhever Schønnebøl som et norsk eksempel på en ny og kritisk holdning til det rettslige fundamentet for trolldomsprosesser. Gilje er for $\emptyset v$ rig av den mening «at juristenes fors $\varnothing \mathrm{k}$ på å forbedre rettssystemet var et mer effektivt inngrep i hekseprosessene enn den teologiske og filosofiske kritikken av hekselæren». ${ }^{28}$ «Schønnebøl synes også å ha ment at trolldom var et fantasiprodukt», legger Gilje til. ${ }^{29}$ I ei grunnbok for norske jusstudenter, skrevet av rettshistoriker Jørn Øyrehagen Sunde, om historien til den norske rettskulturen, betegnes lagmann Mandrup Pedersen Schønnebøl som «ein pioner når det gjaldt å avvise gudsdom og tilståingar framkomne under tortur som bevis». ${ }^{30}$ Sunde framhever at den norske rettsorden ble svekket gjennom den juridiske inkompetansen som knyttet seg til 
førsteinstansdomstolenes håndtering av alvorlige kriminalsaker. Særlig trolldomsprosessene viser at den lokale tingretten var uten sentral styring og kontroll, heter det hos Sunde. ${ }^{31}$ Med henvisning til Finnmark skriver Sunde om en rett som gikk på «sjølstyr», og at aktører som Schønnebøl bidro til en betydningsfull rettskulturell endring ved å slå ned på denne selvstendige rollen. ${ }^{32}$

I et perifert område som etter hvert fikk tradisjon for å føre trolldomssaker i regi av underretten, kan man godt tenke seg til at rettsinstansens autonomi ble retningsgivende for dømmingen. Finnmark kan være et eksempel på nettopp dette. Nicolai Friis, som var amtmann i Finnmark i perioden 1718-1720, uttrykte seg slik etter å ha sett tilbake på tidligere rettsforvaltning og anvendelsen av brutale straffemetoder i amtet: «Embetsmennene i Finnmark synes å ha tatt seg til å diktere ekstraordinære straffer som de ingen hjemmel eller berettigelse hadde til, og at de har dømt og straffet som de selv har funnet for godt». ${ }^{33}$ Mandrup Schønnebøls rettslige atferd kan oppfattes som en reaksjon mot denne rettslige autonomien med tilfeldig dømming og tilsidesettelse av gjeldende lov og rett. Samtidig bør det legges til at den rettslige argumentasjonen med henvisning til dansk lovgivning som Schønnebøl la til grunn for sin dommeratferd i nord, ikke var totalt ukjent i saker som hadde med trolldom å gjøre. Fra tid til annen finner vi samme argumentasjon fra andre steder i Norge. Eksempelvis viste lensinnehaveren i Trøndelag, Jacob Trolle, i 1597 i forbindelse med et rettsoppgjør til en trolldomssak der man urettmessig hadde anvendt vitneutsagn fra allerede dømte trollfolk, altså udediske personer, og at dette ikke var juridisk holdbare for domfellelse. Fogden i Gauldalen, som hadde dømt en kvinne til ild og bål på bakgrunn av slike vitneutsagn, måtte stå til rette for overgrep og uregelmessigheter samt for at kvinnen ikke var blitt dømt av et rettmessig dommerkollegium. ${ }^{34}$

Gjennom sin rettspraksis i Finnmark kan man stille spørsmål om bakgrunnen og motivene for Schønnebøls kritiske, milde og avvisende dømming i saker som har med magi og trolldom å gjøre. Var han en utpreget legalist, paragraf- og lovrytter eller ligger det i tillegg en tidlig humanistisk innstilling med trolldomsskepsis i bunnen? Som det framgår av hans rettspraksis, var han opplagt en ren lovrytter som insisterte på å dømme etter fullt vitnebevis og bokstavtro anvendelse av gjeldende lovgivning, ikke minst i saker som gjaldt trolldomskriminalitet. For Schønnebøl er trolldom ingen unntaksvis forbrytelse, Crimen Exceptum, og det er dermed ikke grunnlag for avvik fra gjeldende rett. På 1400-tallet definerte demonologien hekseri som en superforbrytelse der irregulære rettslige prosedyrer var tillatt for å kunne avsløre et tungt konspiratorisk nettverk som truet samfunnsstabiliteten. Trolldomskriminalitet var en svært alvorlig forbrytelse, en slags organisert form for 
kriminalitet ledet av Satan. Og som sådan var det en forbrytelse som nedkalte Guds vrede. Angrepet på den hellige orden utviklet seg i hemmelighet og var derfor vanskelig å avsløre. Slik ble trolldom og hekseri gjort til unntaksforbrytelser, der man tillot tvilsomme rettsmidler slik som tortur, løgn, vitneprov fra allerede dømte forbrytere, vannprøve og lignende. Forbrytelsens grusomme karakter tillot avvik fra gjeldende rettsprosedyrer. Bestemmelsen av trolldom som en crimen exceptum er grunnleggende for tankegangen i sentrale demonologiske verk som Kramers Malleus Malleficarum og Bodins Demonomani fra henholdsvis 1486 og 1580 og selvsagt for prosesshyppigheten. ${ }^{35}$ På den annen side blir avvisningen av trolldom som en unntaksforbrytelse utover 1600-tallet gjerne trukket fram som en svært avgjørende faktor i utviklingen mot endelig avkriminalisering av hekseri. ${ }^{36}$

Til tross for at Finnmark hadde Norges verste hekseprosesser, var det samtidig her den første systematiske kritikken dukket opp mot heksebrenninger i Norge. Lagmannens kritikk er først og fremst rettet mot den vilkårlige bevisførselen i slike saker ved tingstedene i Finnmark, men han synes dessuten å ha vært en smule skeptisk til selve heksetroen, i alle fall etter hvert. Ut fra domspremissene i saken mot Mari Olsdatter går han nokså langt i å antyde at selve trolldomskunsten har med løgn og innbilning å gjøre. Fortellinger om Anna Rhodius aktive manipulering av de mistenkte mens de satt innesperret $\mathrm{i}$ «hullet» kan ha bidratt til å styrke hans skepsis og tvil. De to dødsdommene fra 1656 kan kanskje tyde på at han var en utpreget paragrafrytter uten noen spesielle humanistiske føringer, men at skepsisen så fikk ny og bredere næring i det brutale møte med trolldomsmistenkte mindreårige barn og torturerte kvinner i 1663.

Utover at Schønnebøl var en rettslærd aktør som aktivt og konsekvent anvendte aktuell dansk-norsk lovgivning, kan man stille spørsmål om motivasjon, inspirasjon og impulser for hans oppfatning av kriminalsaker med trolldomsinnhold. Store deler av hans biografi hviler i historiens mørke, men vi vet $\mathrm{i}$ alle fall at han var en bereist person, ikke bare innenfor fellesunionens grenser, men dessuten med et opphold i Holland i 1620 åra bak seg. Nederland var det første landet i Europa som avviklet dødsstraff i heksesaker. Ingen hollandske hekser ble henrettet etter 1608. Det intellektuelle rettsklima i Holland kjennetegnes av en skeptisk holdning til anklager om hekseri gjennom hele 1600-tallet, noe som resulterte i en restriktiv og forsiktig juridisk håndtering av slike saker. Den handelsøkonomiske framgangen for landet bidro til toleranse og sekularisert mentalitet blant jurister. Om Schønnebøl kjente til og lot seg inspirere av slike mentalitetsstrømninger er det vanskelig å ha noen klar formening om, men han hadde oppholdt seg $\mathrm{i}$ et land hvor det tidlig var risikofylt og vanskelig å anklage mennesker for trolldomsvirksomhet. 
Schønnebøl kom ikke i konflikt med 1617-lovgivningen om trolldom i DanmarkNorge. Hans rettspraksis rokket ikke ved det materielle innholdet i loven, og han hadde ikke behov for å sette loven til side. Han benyttet seg derimot av en bevisst og konsekvent anvendelse av bevisregler og rettsprosedyre. Slike prosessuelle bestemmelser og regler om behandling og vurdering fikk stor betydning, særlig for håndtering av vitnebevis. Schønnebøl fant det rett og slett ikke bevist at de trolldomstiltalte har overtrådt trolldomslovgivningen. Trolldomskriminalitet var en type forbrytelse som skulle underkastes strengt prosessuelle rettsregler. Som lagmann dømte han konsekvent etter såkalt fullt vitnebevis, som var vanskelig å etterkomme nettopp i trolldomssaker. Fullt vitnebevis betydde på 1600-tallet at alvorlige straffesaker krevde minst to uavhengige, frie, troverdige og edsvorne vitnesbyrd. Dessuten ser vi hvordan han innskjerpet og i praksis fulgte opp forordningen fra 1642 omkring vitner og rettens erstatningsansvar for dommer som ble underkjent av en høyere rettsinstans. I lagmannens dom over de to kvinnene i 1656 var det de samme strenge prosedyrene som kom til anvendelse. De ble dømt etter sine egne tilståelser.

Bevisbyrdereglene om tiltaltes egen frivillige, utvungne bekjennelse og forklaring skal legges til grunn for endelig dom, resonnerte lagmannen.

I et manuskript fra om lag 1695 om trolldomsprosessene i Finnmark kom daværende amtmann i Finnmark, Hans H. Lilienskiold (ca.1650-1703), med kraftige utfall mot de frikjennelsesdommene lagmann Mandrup Schønnebøl ga over mistenkte barn og kvinner i juni 1663. ${ }^{37}$ Amtmannen refererte fra rettergangen og siterte Schønnebøl på flere punkter. Lilienskiold var kritisk til holdbarheten i lagmannens juridiske vurderinger og ga mot slutten av 1600-tallet til kjenne et syn på trolldom i pakt med hekseforfølgelsens tidsalder. Ut fra en juridisk betraktningsmåte mente Lilienskiold at det var feil av lagmannen å frikjenne pikebarna og kvinnene i 1663. Og han la til at dersom man skulle følge lagmannens rettsprinsipper «... kom aldri nogen till ilden». I en kommentar til lagmannsdommen over den trolldomsmistenkte Mari Olsdatter på 12 år, skriver Lilienskiold at forestillingen om trolldom som innbilning, og ikke som en kraft, er en tanke som får stå for lagmannens regning. ${ }^{38}$ De to hadde altså vidt forskjellige syn på trolldom. Lilienskiold hadde fortid som lagmann i Bergenhus og dømte atskilling strengere i trolldomssaker såpass seint som i 1680-åra. Amtmann Hans H. Lilienskiolds indignerte kommentar til Schønnebøls handlinger i heksesammenheng tilsier at lagmannen ikke bare dømte mot den vilkårlige bevisførselen i slike saker, men dessuten med et underliggende skeptisk syn på trolldom. Det var i alle fall slik amtmannen oppfattet det - med sin argumentasjon undergravde lagmannen i Hålogaland praktisk talt det rettslige grunnlaget for å føre trolldomsprosesser. 


\section{Appelldomstolene i Europa}

Selv om dommeratferden til lagmannen fra Steigen var både nyskapende og representerer en tidlig motstrøm innenfor norsk og nordisk trolldomsforfølgelse, framstår hans dømming ikke som særegen i en videre europeisk rettskontekst. ${ }^{39}$ Snarere tvert om, hans kritiske dømming er typisk for menn med juridisk kompetanse og uten sterk forankring i lokalsamfunn med opprivende hekseprosesser. Stort sett over hele Europa var appelldomstolene ansvarlige for å slå ned på juridisk misbruk blant overivrige, ulærde og noen ganger korrupte lokale rettsaktører. I de europeiske hekseprosessene fungerte ankeinstansen som en motpol til det som har vært beskrevet som den mørke siden ved rettslig kommunalisme. ${ }^{40}$ En enda sterkere korrelasjonen enn mellom rettens lokale tilknytning og intensiteten av forfølgelse, finner vi i områder av Europa der det ble opprettet egne autonome heksekommisjoner som førte til eskalering av antall heksesaker, slik som enkelte steder i det sørvestlige Tyskland og i Sverige på slutten av 1660-åra og begynnelsen av 1670-åra.

Det klassiske eksemplet på en juridisk skolert enkeltperson som står fram midt under et pågående heksehysteri og får avverget massedrap på såkalte hekser er Alonso De Salazar Frias (1564-1636). Han tilhørte den spanske Inkvisisjonen og fikk i 1609 ansvaret for å undersøke et omseggripende hekseri i Baskerland. Gjennom systematisk skepsis både når det gjaldt heksetro, tilståelser og bevis klarte han å redde et par tusen menneskeliv fra henrettelse. Salazar var universitetsutdannet jurist og var fra mars 1609 knyttet til inkvisisjonen i Logroño i det nordvestlige Spania. Han første oppgave var å gå inn i en voldsom heksepanikk som var under utvikling i det spanske grenseområdet. Han begynte med å oppheve dødsdommer ut fra sviktende bevis og fikk gjenopptatt sakene mot flere kvinner. Gjennom kritiske forhør hvor det framkom motstridende tilståelser og falske anklager klarte Salazar å stoppe noe som kunne ha utviklet seg til Europas verste forfølgelse av hekser. I 1611 reiste han rundt til en rekke mindre landsbyer i det spanske Baskerland, og i løpet av åtte måneder undersøkte han nøye hekseanklager og rykter om ulike hekseaktiviteter, slik som heksenes møtesteder, djevlemerke, flyvesalve og heksesabbat. På forhånd hadde han gitt alle tiltalte et såkalt hekseamnesti slik at de fritt kunne fortelle om sine opplevelser og erfaringer. Han tok for seg nesten to tusen saker. Mange av disse kom fra barnemunn, og Salazar fikk høre lignende fortellinger som Schønnebøl på en helt annen kant av Europa om lag 50 år seinere.

Konklusjonen var entydig. Ingen av historiene var holdbare i rettssammenheng, det meste kunne avvises som drømmefantasier. Ingen klare bevis forelå, og heksenes egne tilståelser var motstridende og holdt ikke vann når de ble konfrontert med hverandre. «Jeg har ikke funnet et 
eneste bevis, ikke engang en mindre indikasjon som kunne tyde på at hekseaktivitet faktisk har funnet sted», var hovedkonklusjonen i kjølvannet av systematisk feltarbeid med avhør og eksperimenteringer. ${ }^{41}$ Etter 1614 avsa den spanske inkvisisjonen ikke en eneste dødsdom i heksesaker. ${ }^{42}$ Dødsdommene som var satt ut i livet i fjellandsbyen Zugurramurdi før Salazars inntreden, ble av inkvisisjonen i 1614 stemplet som et forferdelig feilgrep, og de henrettede heksene ble renvasket post-mortem.

Relativt tidlig på 1600-tallet klarte Parlamentet $i$ Paris, som hadde den øverste jurisdiksjonen over om lag halvparten av den franske befolkningen, gradvis å få kontroll over de lokale rettsinstansenes håndtering av saker om heksekunst. Allerede i 1588 prøvde franske myndigheter å forby vannprøven ved lov. Samtidig forsøkte denne høyeste rettsinstans å få gjennom at førsteinstansen ikke skulle legge hindringer i veien for at heksesaker kunne ankes. I 1624 kom forordningen om at alle alvorlige sakstilfeller av hekseri automatisk skulle appelleres til Paris. Generelt sett var det gjennom hele perioden nokså enkelt for mistenkte trollfolk å få anket sakene sine fra lokale domstoler til Parlamentet i Paris. Dette i motsetning til eksempelvis Finnmark der det enten var retten, rettsapparatets forvaltere eller ressursrike enkeltpersoner, gjerne handelsborgere, som anket slike saker. Anvendelsen av rettshierarkiet i Frankrike førte til at de fleste dødsdommene fra underretten ble omgjort. Avgjørelsen om å begrense rettsforfølgelsen av trolldomsfolk kom i 1640. Og, til slutt, i 1682, kom Ludvig XIVs endelige edikt mot hekseforfølgelser i Frankrike. ${ }^{43}$ Juridisk og politisk sentralisering betydde avkriminalisering av trolldomskriminalitet. Frankrike, Europas mest folkerike stat på 1600-tallet, har gått over i historien som et land med få hekseprosesser til tross for at Europas fremste juridisk skolerte demonologer, slik som Jean Bodin og Pierre De Lancre, gjorde sitt for å definere hekseri som en ekstraordinær unntaksforbrytelse som krevde egne rettsprosedyrer. Jean Bodins lære hadde størst gjennomslagskraft i lavere rettsinstanser, slik som provinsparlamentene og blant lokalt plasserte franske jurister. For i det hele tatt å kunne rettsforfølge hekser på en effektiv måte, var det nødvendig å redefinere forbrytelsen og senke bevisbyrden, det vil si å gjøre hekseri til en Crimen Exceptum, slik vi har sett. Og det er rett og slett grunnen til at de lærde rettsmanualene til Bodin og Kramer (han med Heksehammeren fra 1486) ble så godt mottatt av det lavere sjiktet i datidens rettshierarki.

I europeisk trolldomshistoriografi har det vært lansert flere teser om hvilke faktorer som var med på å avkriminalisere trolldom. Noen har lagt vekt på avgjørende endringer innenfor teologien, mens andre mener at det er juridiske faktorer som ligger til grunn for domstolenes skepsis og avvisning av anklager om trolldom utover andre halvdel av 1600- 
tallet. ${ }^{44}$ Det at Lagmannen i Steigen kunne dømme slik han gjorde fra 1647 og utover andre halvdel av 1600-tallet understreker imidlertid at det var mulig å kritisere herskende rettspraksis i trolldomssaker uten nødvendigvis å representere et brudd med selve det teologiske fundamentet for heksetroen. ${ }^{45}$

I siste instans har oppfatningen av en demonisk undergravende indre fiende sitt utspring i teologiske spekulasjoner. Endringer i det teologiske grunnsynet vil derfor være av fundamental betydning for fenomener som hekseforfølgelse. Sakte, men sikkert, kan vi etterspore en endring i oppfatningen av Gud utover 1700-tallet. Dessuten erstattes tidligere apokalyptiske visjoner med sivilisasjonsoptimisme. Guddommen og dermed demonverdenen suspenderes både fra samfunnet og naturen. Fra å være en ytterst aktiv kraft i den jordiske, verdslige verden, forvises djevelen til en passiv tilværelse i sitt mørke og trange dyp. Sammen med den apokalyptiske historieoppfatningen går den vitenskapelige hekselæren, demonologien, gradvis i oppløsning.

Forholdet mellom juss og religion er en annen viktig faktor. Større grad av vitenskapeliggjøring og sekularisering av jussen betydde at teologien mister sin innflytelse over den. For å kunne dømme i saker som var relatert til magi, krevde dommerne strengere bevis enn tidligere. Dermed nådde trolldomsanklager ikke lenger opp i rettsapparatet. Bibelens lovbestemmelser kom mer og mer i bakgrunnen. Dessuten fikk man et nytt syn på Mosebøkene. Straffebestemmelsene i Guds lov var ikke lenger universelle, men hadde begrenset historisk gyldighet. 1700-tallets rettspleie kjennetegnes av en gradvis oppgivelse av den mosaiske rettsforståelsen. I Danmark-Norge spilte den mosaiske rett imidlertid fortsatt en betydelig rolle utover 1700 -tallet. ${ }^{46}$ I andre land tar denne utviklingen til allerede på 1600tallet.

I de fleste land kommer endringen innenfor rettsvitenskapen forut for endringer i det teologiske ståsted. Standardisering og sentralisering av statens juridiske apparat gjennom enevoldsstaten betydde reduksjon eller opphør av hekseprosesser. Utbygging av den rettslige instansordningen med ankemuligheter førte med seg større kontroll med lavere rettsinstanser, inkludert suspensjon av det tidligere fogderegimet. Gjennom delvis avlokalisering av rettsapparatet brøt forfølgelsessystemet sammen. Disse utviklingstrekkene i rettsvesenet kan etterspores over store deler av Europa før opplysningstidens inntog. Schønnebøls kritiske dømming i Finnmark er et konkret eksempel på hvordan et slikt juridisk brudd med fortiden kan foregå og igangsette en mer omfattende mentalitetsendring i rettsforvaltningen. De juridiske gyldighetskravene tok nye former og skjøv trolldom til side som en kriminalitetstype. 
Både når det gjelder teologiske og juridiske forklaringsteser, har den sentrale rollen og betydningen til enkeltpersoner vært understreket. Eksemplet Mandrup P. Schønnebøl viser hvor stor betydning den individuelle faktoren var for hekseprosessenes forløp og avviklingsfase i bestemte regioner. Dessuten er han og flere andre uredde maktpersoner et uttrykk for at det gjennom hele «heksetiden» eksisterte kritiske stemmer og skeptiske synspunkter. Det var aldri tale om noen lukket kollektiv forfølgelsesmentalitet når det gjeldt trolldom, magi og hekseri. Det er disse stemmene som viser vei ut av denne typen menneskeforfølgelse. Den uredde og myndige lagmannen fra Steigen blir på sett og vis helten i fortellingen om de brutale trolldomsprosesser, en fortelling som ellers har få lyspunkter.

\section{English Abstract:}

Judgments at regional level in north Norwegian witchcraft trials 1647-1680.

The northeast county of Finnmark had not only the worst persecution of so-called witches in Norway, but also amongst the most severe witch-hunts in Europe during the 17th-century. Sources from the very late 17th century, reveal a total population of approximately 3200 inhabitants, of which 1500 were Sami - the native people of northern Europe. Among these as many as more than 138 people were accused of sorcery from 1593-1692. At least 92 individuals, mostly women, got the death sentence and burned at the stake. Trying to acquitting people of accusations of witchcraft the senior judge, Mandrup P. Schönnebøl (1603-1682) of the Court of Appeal in the northern part of Norway (Hålogaland Lagmannsdømme), represents a countercurrent towards these grotesque numbers. The article shows and discusses his argument and law references in comparison with similar cases throughout Europe.

RUNE BLIX HAGEN, førsteamanuensis i historie, Institutt for historie og religionsvitenskap (IHR), Fakultet for humaniora, samfunnsvitenskap og lærerutdanning (HSL), UiT Norges arktiske universitet, 9037 Troms $\varnothing$. E-post: rune.hagen@uit.no

Websted: http://ansatte.uit.no/rune.hagen/hagen.htm

\section{KILDER}

Den rette Jüdske Lowbog/Som er offuer seet Corrigerit oc forbedrit/effter det Exemplar/som anno MDLXXXX (1590) er udgangen De nu paa ny Igjen oplagt Cum Gratia \& Priuilegio Serenissimæ Regiæ Majestatis, Prentet i Kiøbenhaffn/Aff Peder Haake/Paa Jørgen Holsts Bogf. 1642. (lovsamling)

Fylkesmannen i Finnmark, Arkivstykke 2543 (saker fra 1663 og 1667), Statsarkivet i Tromsø. 
Nordland \& Finmarkens Lagstol, Lagtingsprotokoller for Nordland og Finnmark 1647-1682, Statsarkivet i Trondheim, kopi ved Statsarkivet i Tromsø.

Tingb $\phi k e r$ fra Vardфhus 1648-1685, Sorenskriveren i Finnmark, Statsarkivet i Troms $\emptyset$.

Forordning om troldfolk og deres medvidere 12. oktober 1617

http://danmarkshistorien.dk/leksikon-og-kilder/vis/materiale/forordning-om-troldfolk-ogderes-medvidere-12-oktober-1617/

(Sist sjekket 21/4-2015)

\section{LITTERTUR}

(Alle webadresser er sist sjekket og funnet i orden 21/4-2015)

Alm, Ellen Janette. Statens rolle i trolldomsprosessene i Danmark og Norge på 1500- og 1600-tallet. En komparativ unders $\phi$ kelse. Hovedoppgave i historie, Troms $\varnothing 2000$.

Fulltekst: http://munin.uit.no/handle/10037/5855

Alm, Ellen. Trondheims siste heksebrenning. Trolldomsprosessen mot Finn-Kirsten, Museumsforlaget, Trondheim 2014.

Bever, Edward. Popular Witch Beliefs and Magical Practices, i The Oxford Handbook of Witchcraft in Early Modern Europe and Colonial America, Edited by Brian P. Levack, Oxford University Press, Oxford 2013: 50-68.

Brodahl, Joh. E. Litt om adelsslegtene Staur, Schфnnebøl og Munchegaard i Nordland, Bodø 1915 (Særtrykk av Nordlandsposten).

Brun, Håkon. Heksa på Kleppstad og andre «hekser», Årbok for Vågan 1993: 19-25.

Dalen, Ingebjørg Aamlid. Ei tjenestejente, to prester og ett spфkelse: en unders $\varnothing k e l s e$ av trosforestillinger, rettspraksis og resepsjonshistorie i Nille-saken fra Steigen 1687 -88. Masteroppgave i historie, Troms $\emptyset$, våren 2011.

Fulltekst i Munin: http://munin.uit.no/handle/10037/3486

Dillinger, Johannas. Politics, State-Building, and Witch-Hunting, i The Oxford Handbook of Witchcraft in Early Modern Europe and Colonial America, Edited by Brian P. Levack, Oxford University Press, Oxford 2013: 528-547.

Falkanger, Aage Thor. Lagmann og lagting i Hålogaland gjennom 1000 år, Universitetsforlaget, Oslo 2007.

Falkanger, Aage Thor. Lagmannen og Lagtinget i Hålogaland, Ottar, nr. 300, 2-2014: 11-18.

Fygle, Svein. Steigen bygdebok, bind 3 Nordfold: fjorden og folket, Steigen 1991.

Geschiere, Peter. Witchcraft, Intimacy, and Trust. Africa in Comparison, University of Chicago Press, Chicago 2013.

Gilje, Nils. Heksen og humanisten. Anne Pedersdatter og Absalon Pederss $\phi n$ Beyer - en historie om magi og trolldom i Bergen på 1500-tallet, Bergen 2003 (2010). 
Goodare, Julian. Witchcraft in Scotland, i The Oxford Handbook of Witchcraft in Early Modern Europe and Colonial America, Edited by Brian P. Levack, Oxford University Press, Oxford 2013: 300-317.

Gudbrandson, Terje, Fra Bodø i dansketida, Bodø Bygdeboknemd, Oslo 1974.

Guillou, Jan, Heksenes forsvarerer. En historisk reportasje, Cappelen, Oslo 2002.

Hagen, Rune Blix, Bodin, Jean (1529/1530-1596), i Encyclopedia of Witchcraft. The Western Tradition, Richard M. Golden, Editor, Volume 1, A-D, Denver and Oxford 2006: 129-131.

Hagen, Rune Blix. Hekser - fra forfølgelse til fortryllelse, Oslo 2010.

Hagen, Rune Blix. Ved porten til helvete. Trolldomsprosessene i Finnmark, Cappelen Damm, Oslo 2015.

Hasselberg, Kåre og Svein Tore Dahl. Embetsmenn i Nord-Norge i tiden 1536-1700, Trondheim 1999.

Henningsen, Gustav (ed.) The Salazar Documents: Alonso de Salazar Frias and Others on the Basque Witch Persecution, Brill, Leiden and Boston 2004.

Henningsen, Gustav. Basque Country, Encyclopedia of Witchcraft. The Western Tradition, Richard M. Golden, Editor, Volume 1, A-D, Denver and Oxford 2006: 93-97.

Johansen, Jens Christian V. Da Djoevelen var ude... Trolddom I det 17. Arhundredes Danmark, Odense 1991.

Johansen, Else Lilly. Trolldomsforskning i Norden ca 1970-2010 - en forskningsoversikt, masteroppgave i historie, Troms $\varnothing 2011$. Fulltekst: http://munin.uit.no/handle/10037/3724

Kallestrup, Louise Nyholm. I pagt med Djavelen. Trolddomsforestillinger og trolddomsforfølgelser I Italien og Danmark efter reformationen, København 2009.

Kamen, Henry. Spain. Encyclopedia of Witchcraft. The Western Tradition, Richard M. Golden, Editor, Volume 4, Q-Z, Denver and Oxford 2006: 1069-1070.

Knutsen, Gunnar W. Trolldomsprosessenes opphør i Skandinavia, Historisk tidsskrift, Nummer 4, 2005: 593-611.

Krause, Virginia. Witchcraft, Demonology, and Confession in Early Modern France, Cambridge University Press, New York 2015.

Krogh, Tyge. Oplysningstiden og det magiske. Henrettelser og korporlige strafe i 1700-tallets første halvdel, København 2000. 
Levack, Brian P. The Decline and End of Witchcraft Prosecutions, i The Oxford Handbook of Witchcraft in Early Modern Europe and Colonial America, Edited by Brian P. Levack, Oxford University Press, Oxford 2013: 429-446.

Lilienskiold, Hans H. Trolldom og ugudelighet i 1600-tallets Finnmark, redigert og bearbeidet av Rune Blix Hagen og Per Einar Sparboe, Tromsø 1998

Monter, William. Appeals, i Encyclopedia of Witchcraft. The Western Tradition, Volume 1, A-D, Richard M. Golden, Editor, ABC-CLIO, Denver and Oxford 2006: 48-51.

Monter, William. Witchcraft Trials in France, i The Oxford Handbook of Witchcraft in Early Modern Europe and Colonial America, Edited by Brian P. Levack, Oxford University Press, Oxford 2013: 218-231.

Niemi, Einar. Vads $\phi s$ historie, bind 1. Fra фyvar til kjøpstad (inntil 1833), Vadsø kommune, Vadsø 1983.

Njåstad, Magne. Kunnskapen som forsvant. Demonologi som vitenskap, i En sann historiker. Festskrift til Svein Henrik Pedersen. Redigert av Jan Frode Hatlen og Pål Thonstad Sandvik, Trondheim 2007: 59-70.

Normann, Henrik. Schønnebølenes saga i Nordland, Årbok for Steigen 1983: 69-74.

Næss, Hans Eyvind. Trolldomsprosessene i Norge på 1500-1600-tallet, Oslo 1982.

Næss, Hans Eyvind, Med bål og brann. Trolldomsprosessene i Norge, Stavanger 1984.

Næss, Hans Eyvind. Hekseprosessen mot Turid Litlasund, i Den nordiske histories fader Tormod Torfaus, Karmøy kommune, Karmøyseminaret 2002: 50-61.

Næss, Hans Eyvind. Fiat justitia! Lagmennene i Norge 1607-1797, Riksarkivarens skriftserie 42, Oslo 2014.

Peters, Edward. Crimen Exceptum, i Encyclopedia of Witchcraft. The Western Tradition, Richard M. Golden, Editor, Volume 1, A-D, Denver and Oxford 2006: 232-233.

Rowlands, Alison. Witchcraft and Gender in early Modern Europe i The Oxford Handbook of Witchcraft in Early Modern Europe and Colonial America, Edited by Brian P. Levack, Oxford University Press, 2013: 449-467.

Sandmo, Erling. Tid for historie. Universitetsforlaget, Oslo 2015.

Sandnes, Jørn. En hekseprosess fra Stod i 1640-åra. Nord-Trøndelag Historielags årbok 1981: 64-78.

Schøning, Jakob. Lagmennene i Nordland og Finnmark mellem omtr. 1200 og 1797, Håldygminne Hefte 4/1930, 1, 2 og 3-4/1931. 
Sogner, Sølvi. Hva kan tingbøkene fortelle om barns rettsstilling på 1600-tallet? i Rett og historie. Festskrift til Gudmund Sandvik, redigert av Dag Michalsen og Knut Sprauten, Universitetet i Oslo 1997: 82-89.

Soman, Alfred. The Parlement of Paris and the Great Witch Hunt (1562 - 1640), Sixteenth Century Journal, 9, No.2/1978.

Soman, Alfred. Deviance and criminal justice in Western Europe, 1300-1800: An essay in structure, Criminal Justice History, 1, 1980.

Soman, Alfred. Decriminalizing witchcraft: Does the French experience furnish a European Model? Criminal Justice History, 10, 1989.

Sunde, Jørn Øyrehagen, Speculum legale - rettsspegelen. Ein introduksjon til den norske rettskulturen si historie i eit europeisk perspektiv, Fagbokforlaget, Bergen 2005.

Vogt, Helle. Likewise no one shall be tortured. The use of judicial torture in early modern Denmark, i Scandinavia Journal of History, 39, 1/2014: 78-99.

Willoch, G.I. Spredte trekk fra før og nå, i Vardøhus Festning 650 år Jubileumsskrift, redaktør oberst G. I. Willoch, Oslo 1960: 161-163.

Willumsen, Liv Helene. Dømt til ild og bål. Trolldomsprosessene i Skottland og Finnmark, Orkana Akademisk, Stamsund 2013.

Wyporska, Wanda. Witchcraft in Early Modern Poland, 1500-1800, Palgrave Macmillan, Hampshire 2013.

\section{Noter}

Et tidligere utkast av artikkelen har vært lagt fram ved forskerseminar for historie ved UiT Norges arktiske universitet. Ved Norske historiedager 2014, Universitetet i Oslo la jeg fram deler av teksten til diskusjon. Et utdrag ble dessuten presentert gjennom et foredrag under seminaret «Tinget som demokratisk møtested» ved Universitetet i Nordland i november 2014. Ved disse anledningene fikk jeg en rekke fruktbare innspill som jeg satte stor pris på og som har hatt betydning for den endelige utformingen av teksten. To anonyme fagfeller har kommet med nyttige råd om presiseringer og utdyping. En av dem har sågar tatt seg tid til å rette opp uheldige formuleringer og feilaktigheter i selve teksten. Stor takk til alle bidragsytere, meget verdifullt!

\footnotetext{
${ }^{1}$ Lagmannsdom fra Vardø torsdag 25. juni 1663. Originaldokumentet finnes i arkivet fra Fylkesmannen i Finnmark, Arkivstykke 2543, dokument 37. Her gjengitt i mer moderne språkdrakt fra Lilienskiold 1998: 206. 'Da effterdj att forschne: Marj Olßdatter er ichun et barn att Regne paa, och haffue Löyet paa sig selff och andre medt, Ved ieg iche her om Anderledi $\beta$ att Kiende och dömme j dend sag /: End att forbete: Lille Töes $\beta$ marj Oluff $\beta$ daatter Vehre frj for stedet och till Bergen fölgactig och der $\mathrm{j}$ Tuchthußet att forbliffue Nogen stund.' (transkribert fra den originale kildeteksten).

2 «Udedisk» viser til en person som har begått en udåd og som oppfattes som uærlig og dermed uten vitnehabilitet i rettssammenheng.

${ }^{3}$ Sunde 2005: 341 .

4 "Witchcraft historians now agree that there were different types and degrees of belief regarding witchcraft, and that there were elements of belief and disbelief in the works of all demonologists", skriver den amerikanske historikeren Brian P. Levack, 2013: 9.

${ }^{5}$ Næss 2014: 184-185.

${ }^{6}$ I perioden 1634-1647 kjøpte Schønnebøl opp relativt store mengder jordegods i Salten-området med utgangspunkt i den skattefrie adelsgården Bertnes, se Gudbrandson 1974: 53-54.
} 
${ }^{7}$ Falkanger 2007: 14.

${ }^{8}$ Det er flere uoverensstemmelser blant forfattere når det gjelder tidsangivelse for Mandrup Pedersen

Schønnebøls biografi og gjøremål, min framstilling er for det meste basert på Brodahl 1915 og Falkanger 2007.

${ }^{9}$ Det dreier seg opprinnelig om den Københavnske recess av 6/12-1547, artikkel 8 (om vitneutsagn) og 17 (om tortur), som så blir gjentatt i Den Koldingske recess av 13/12-1558, artikkel 18 og 19. Artikkel $18 \mathrm{i}$ den Koldingske recess (artikkel 8 i den Københavnske recess) har følgende ordlyd: "... ey heller nogen udediske Mendiske, eller nogre andre, som forwunden er for nogen werligh sag, Tyffue, Troldkarle elle Troldqwinder, staa till troende, enthen udi Widnisbyrdt eller i andre Maade, ehuad the wille sige eller widne paa nogen". Av artikkel 19 om tortur går det fram at ingen skal pinlig forhøres før vedkommende er dømt. Bestemmelsene er inntatt i Den rette Jüdske Lowbog fra 1642. Schønnebøl anvendte disse recessene når han frifant mistenkte trollkvinner og trollunger i Finnmark både i 1647, 1653 og 1663. I tillegg brukte han andre strengt legallistiske argumenter, eksempelvis det faktum at det ikke eksisterte noen lovhjemmel for vannprøven. Og han viste til gjeldende dansk-norsk rett når han ila anklagere, private og offentlige, erstatningsansvar ved falske, lite holdbare anmeldelser. Se Alm 2000: 56-58 og Vogt 2014: 81 og lovgjennomgangen av kravene til vitneførsel hos Næss 1982: 184 .

${ }^{10}$ Sogner 1997: 85.

${ }^{11}$ Nordland \& Finmarkens lagstol 1647: fol.005. (Lagting på Vardøhus 4. juni 1647).

${ }^{12}$ Alle dokumentene fra Lagtingets sesjoner i Finnmark fra 1653 er transkribert av Per Einar Sparboe og er gjengitt i konsentrert form hos Falkanger 2007: 126-132.

${ }^{13}$ Mønstret med lokale rettsinstanser som dømmer mer forsiktig og mildere umiddelbart etter kritikk fra overordnet hold er gjennomgående for europeisk rettspraksis i hekseprosesser, se Goodare 2013: 309.

${ }^{14}$ TB 4, 5/4-1654, fol. 002a.

${ }^{15} \mathrm{Jeg}$ har gjort rede for hele den nokså komplekse saksgangen mot de tre kvinnene i kapittelet «Lille Maries historie», se Hagen 2010: 26-43.

${ }^{16}$ Rowlands 2013: 461.

${ }^{17}$ Hele djevlepaktparagrafen har følgende formulering: «Hvis rette trolfolk belangis er, som med diefvelen sig bebundit hafver eller med hannom omgaais, med dennom skal forholdis epter lougen och recessen; meden de, som sig med saadanne folk indvikler och ved deris troldom noget sig understaar at lade forrette, skal straffis paa deris hals uden ald naade». Se http://danmarkshistorien.dk/leksikon-og-kilder/vis/materiale/forordning-omtroldfolk-og-deres-medvidere-12-oktober-1617/

${ }_{18}^{18}$ Brun 1993: 22-23. Under et lagting i Steigen 25. Juni 1666 bekrefter Schønnebøl frikjennelsesdommen over Karen Pedersdatter, se Nordland og Finnmark lagstol, Protokoll 1666-1690, fol. 37b-38a.

${ }^{19}$ Se gjennomgangen hos Dalen 2011: 79-81.

${ }^{20}$ Nordland og Finnmark lagting, del 2, 1663-1668, Fol. 151 (23/6-1663).

${ }^{21}$ Fylkesmannen i Finnmark, arkivstykke 2543, referat fra tingretten i Vardø 27. Juni 1667. I sine studier av trolldomsprosessene i Finnmark forteller amtmann Hans H. Lilienskiold at Mari Olsdatter etter hvert ble gift og avgikk ved døden mot slutten av århundret, se Lilienskiold 1998:201.

${ }^{22}$ Findmarkens Laug-tings Protocoll Anfanget 1.6.7.1, 1671, fol. 3-3b, Statsarkivet i Troms $\varnothing$.

${ }^{23}$ Alm 2014: 130, se også s. 61 og s. 125. Flere eksempler hos Næss 2014: 365-366.

${ }^{24}$ Næss 1982: 268-269 og Næss 2014:364-365, se også Alm 2000: 167-168, Sunde 2005: 188 og Willumsen 2013: 273. Næss, og etter han Alm og Sunde, tar imidlertid 1653 som utgangspunkt for «det første eksemplet på den nye kritiske holdningen», og ikke 1647. Det har sammenheng med at Næss ikke har kjent til lagtingsreferatet fra 1647. Jeg flytter det første eksemplet på kritisk dømming i norsk trolldomssaker seks år bakover i tid. Slik sett er altså Schønnebøl tidligere ute enn man lenge har trodd.

${ }^{25}$ Næss 1984: 156.

${ }^{26}$ Niemi 1983: 220.

${ }^{27}$ Falkanger 2007: 148 og 152. Se også Falkanger 2014: 16-17, hvor han igjen beskriver Schønnebøl som en humanist og dyktig jurist.

${ }^{28}$ Gilje 2003: 246.

${ }^{29}$ Ibid.

${ }^{30}$ Sunde 2005: 188. Schønnebøl var riktignok tidlig ute med kritisk dømming i dansk-norske trolldomssaker, men han er ikke enestående. I en sak fra Nord-Trøndelag i 1649 fikk «fullmektig» Ludvig Madsen frikjent Lisbet Mikkelsdatter ut fra begrunnelsen om at de alvorlige trolldomsanklagene mot henne utelukkende var framsatt av et «løsaktig menneske, en misdeder og en tvihermer». Vedkommende, Marit Knutsdatter, var dømt og henrettet for trolldomskunst og hadde under rettsprosessen flere ganger motsagt seg selv («tvihermer»), argumenterte Madsen og fikk renvasket Lisbet. Saken er gjengitt hos Sandnes 1981: 70-71.

${ }^{31}$ Sunde 2005: 341 .

${ }^{32}$ Sunde 2005: 196. Med henvisning til juridisk praksis i Danmark på 1500- og 1600-tallet har Helle Vogt (2014) argumentert for det stikk motsatte synet, nemlig at høyere plasserte juridiske autoriteter var mer tilbøyelige til å anvende tortur enn den lokale underretten - hun skriver da også om en «Danish Sonderweg», 2014: 92. 


\footnotetext{
${ }^{33}$ Sitert hos Willoch 1960: 163.

${ }^{34}$ Njåstad 2007: 60. For øvrig går ideen om at visse mennesker er å betrakte som vanærede langt tilbake i europeiske rettshistorie. Et grunnleggende rettsprinsipp i den tidligste romerretten fra 100-tallet er at visse personer erklæres som vanærede som følge av umoralsk framferd, slik som tyveri og svindel. Personer som er $\mathrm{d} ø \mathrm{mt}$ for slike lovbrudd har ikke vitnehabilitet i rettsammenheng. Takk til masterstudent Tor-Ivar Krogsæter for henvisningen til betydningen av det romerske begrepet infamia («vanære»).

${ }^{35}$ Hagen 2006: 130. Disse to demonologiske tekstene er spesielt viktige fordi begge inneholder sentrale deler med direkte instruksjon i rettslig behandling av trolldomskriminalitet. Jean Bodins bok hadde eksplisitt skepsisen til franske høyesterettsdommere som den primære målgruppen for sin utlegging av rettspraksis i heksesaker, se Krause 2015: 86-87.

${ }^{36}$ Om konstruksjonen av trolldom som en unntaksforbrytelse, se Peters 2006: 232-233, og Levack 2013: 475.

${ }^{37}$ Lilienskiold 1998: 235-241.

${ }^{38}$ Lilienskiold 1998: 207.

${ }^{39}$ Om trolldomsprosessenes opphør i Danmark og ellers i Skandinavia, se Knutsen 2005, Krogh 2000, Johansen 1991:139- 160 og Johansen 2011: 34-35.

${ }^{40}$ Dillinger 2013: 539-541, se også Bever 2013: 61 og Monter 2006: 48. Med utgangspunkt i eget feltarbeid fra Kamerun mener den hollandske antropologen Peter Geschiere at den Europeiske modellen har gyldighet for forståelsen av hekseforfølgelsen i mange afrikanske land i dag, se Geschiere 2013: 108-110.

${ }^{41}$ Henningsen 2004: 330. "I have not found a single proof, not even the slightest indication, from which to infer that an act of witchcraft has actually taken place."

${ }^{42}$ Kamen 2006: 1070, Henningsen 2006: 95. Alonso de Salazar Frias er for $\emptyset$ vrig en av de som har gitt navnet til Jan Guillous historiske reportasjebok Heksenes forsvarere fra 2002, se særlig s.294-350.

${ }^{43}$ Soman 1989: 5-6. Om sammenhengen mellom politisk sentralisering og nedgangen $i$ antall heksesaker i Frankrike, se Soman 1978. Den nokså enkle tilgangen for tiltalte til å anke trolldomssaker fra provinsdomstolene i Frankrike er behandlet av Monter 2013: 219-220. Se også Erling Sandmos kommentar til behandlingen av hekseprosesser i Frankrike, 2015: 96.

${ }^{44}$ Knutsen 2005: 609-610, Hagen 2010: 162-163. Se også diskusjonen av sannhetsbegrepet i historieskrivningen hos Sandmo 2015: 200-205.

${ }^{45}$ Wyporska 2013: 174.

${ }^{46}$ Krogh 2000: 16. Avviklingsfasen av den mosaiske rettsforståelsen i Danmark-Norge er grundig unders $\varnothing \mathrm{kt}$ av Tyge Krogh i hans bok fra 2000.
} 